\title{
O gênero Nectandra Rol. ex Rottb. (Lauraceae) no Estado do Paraná, Brasil ${ }^{1}$
}

\author{
Mireille Maria Franco Zanon ${ }^{2, \dagger}$, Renato Goldenberg ${ }^{3}$ e Pedro Luís Rodrigues de Moraes ${ }^{4}$
}

Recebido em 19/07/2007. Aceito em 27/03/2008

\begin{abstract}
RESUMO - (O gênero Nectandra Rol. ex Rottb. (Lauraceae) no Estado do Paraná, Brasil). Nectandra Rol. ex Rottb. apresenta 14 espécies no Paraná: Nectandra angustifolia (Schrader) Nees \& Mart., N. cissiflora Nees, N. cuspidata Nees \& Mart., N. grandiflora Nees \& Mart., N. hihua (Ruiz \& Pav.) Rohwer, N. lanceolata Nees \& Mart., N. leucantha Nees \& Mart., N. megapotamica (Sprengel) Mez, N. membranacea (Sw.) Griseb., N. nitidula Nees \& Mart., N. oppositifolia Nees \& Mart., N. paranaensis Coe-Teixeira, N. puberula (Schott) Nees e N. reticulata (Ruiz \& Pav.) Mez. São apresentados chave para identificação e descrições de cada espécie, assim como ilustrações e dados sobre sua fenologia e distribuição. Nectandra hihua é citada pela primeira vez para o Estado.
\end{abstract}

Palavras-chave: flora, Lauraceae, Nectandra, Paraná, taxonomia

ABSTRACT - (The genus Nectandra Rol. ex Rottb. (Lauraceae) in Paraná State, Brazil). Nectandra Rol. ex Rottb. has 14 species in Paraná: Nectandra angustifolia (Schrader) Nees \& Mart., N. cissiflora Nees, N. cuspidata Nees \& Mart., N. grandiflora Nees \& Mart., N. hihua (Ruiz \& Pav.) Rohwer, N. lanceolata Nees \& Mart., N. leucantha Nees \& Mart., N. megapotamica (Sprengel) Mez, N. membranacea (Sw.) Griseb., N. nitidula Nees \& Mart., N. oppositifolia Nees \& Mart., N. paranaensis Coe-Teixeira, N. puberula (Schott) Nees and N. reticulata (Ruiz \& Pav.) Mez. We present an identification key and species descriptions, as well as illustrations and data on phenology and geographic distribution. N. hihua is cited for the first time in Paraná State.

Key words: flora, Lauraceae, Nectandra, Paraná, taxonomy

\section{Introdução}

Lauraceae é uma família de Angiospermas que apresenta distribuição majoritariamente pantropical, com poucos membros ocorrendo em clima temperado (Rohwer 1993b). São 50 gêneros e entre 2.500 e 3.000 espécies (Rohwer \& Kubitzki 1993), melhor representados nas Américas e Ásia, mas que ocorrem também na Austrália, Madagascar e mais esparsamente na África Central (Werff \& Richter 1996). A família pertence à ordem Laurales, que está posicionada entre as linhagens basais de Angiospermas (Cronquist 1988; APG II 2003). O gênero Nectandra foi descrito por Rottboel em 1778, com duas espécies, baseado num manuscrito de Rolander (Rohwer 1993a). Hoje são aceitas 114 espécies com distribuição restrita às Américas tropical e subtropical, sendo 43 brasileiras (Baitello 2003). O nome do gênero provém de uma interpretação errônea, dada pelo autor, ao conceber que os estames eram glândulas nectaríferas e que somente as valvas eram estames (Rohwer 1992), embora parte dos estames realmente apresente glândulas de néctar. Outra característica dos estames no gênero é a disposição dos locelos em arco, característica esta considerada diagnóstica para o seu reconhecimento (Bernardi 1962; Rohwer 1993a).

Em termos filogenéticos, Nectandra é um gênero provavelmente parafilético (Rohwer 2000), relacionado mais proximamente com Pleurothyrium e com as espécies neotropicais de Ocotea (Chanderbali et al. 2001). As espécies de Nectandra são importantes do ponto de vista econômico: sua madeira é usada para construção civil e indústria moveleira, sendo considerada de boa qualidade, com exceção daquelas que podem desprender odor desagradável, o que limita seu uso (Rohwer 1993a).

Tendo em vista a abundância de espécies de Lauraceae em quase todas as formações fitogeográficas

\footnotetext{
Dissertação de Mestrado da primeira Autora

2 Rua dos Pereira 70, 83800-000 Campo do Capão, Mandirituba, PR, Brasil

3 Universidade Federal do Paraná, Departamento de Botânica, Setor de Ciências Biológicas, C. Postal 19031, 81531-970 Curitiba, PR, Brasil

4 Universidade Estadual de Campinas, Instituto de Biologia, Departamento de Botânica, C. Postal 6109, 13083-970 Campinas, SP, Brasil

† In memorian. Mireille Maria Franco Zanon nasceu em 16/VIII/1975, graduou-se, em 2004, em Ciências Biológicas na Universidade Tuiutí do Paraná. Concluiu, em 2007, o Mestrado em Botânica, na Universidade Federal do Paraná.Veio a falecer subitamente em 13/XI/2008, deixando marido e dois filhos. O Departamento de Botânica da UFPR sente sua perda, pois lá Mireille amealhou um grande respeito, decorrente de sua seriedade e competência.
} 
do Paraná e a grande quantidade de coletas depositadas nos herbários paranaenses, este trabalho tem como objetivo contribuir para o estudo da flora do Paraná onde, para a família, não existe monografia alguma publicada. Neste tratamento são apresentadas chave de identificação, descrições e distribuição geográfica de todas as espécies de Nectandra ocorrentes no Estado.

\section{Material e métodos}

O Paraná está situado na região sul do Brasil, entre $22^{\circ} 29^{\prime} 30^{\prime \prime}-26^{\circ} 41^{\prime} 00^{\prime \prime}$ S e $48^{\circ} 02^{\prime} 24^{\prime \prime}-54^{\circ} 37^{\prime} 38^{\prime \prime} \mathrm{W}$. Apresenta área de $199.323 \mathrm{~km}^{2}$, ocupando $2,5 \%$ da superfície total do país. Está dividido em cinco grandes unidades fitogeográficas (Roderjan et al. 2002). A Floresta Ombrófila Densa (FOD) está situada a leste do Estado, ocorrendo na Planície Litorânea, Serra do Mar e Vale do Ribeira, entre 0 e cerca de $1.800 \mathrm{~m}$ de altitude, apresentando chuvas bem distribuídas ao longo do ano. A Floresta Ombrófila Mista (FOM) está situada a oeste da Serra do Mar, e ocupa as porções planálticas do Estado, entre 800 e $1.200 \mathrm{~m}$ de altitude. Apresenta chuvas bem distribuídas ao longo do ano, mas as temperaturas são baixas, com ocorrência frequente de geadas. A Floresta Estacional Semi-decidual (FE) está situada ao norte e oeste do Estado e nos vales dos rios formadores da bacia do rio Paraná, abaixo de $800 \mathrm{~m}$. Está sujeita à ocorrência de geadas, e tem como característica marcante a deciduidade de árvores do dossel durante a estação seca, que é relativamente bem marcada. A Estepe (ES) ocorre geralmente nas porções mais elevadas dos três planaltos paranaenses, ocupando por volta de $14 \%$ da superfície do Estado. Compreende extensas áreas com vegetação herbácea, entremeada por capões e florestas de galeria nos locais mais baixos. A Savana (CE), ou "cerrado", está localizada nas regiões norte e nordeste do Estado, abrangendo em torno de $1 \%$ da sua superfície. No Paraná são encontrados os fragmentos mais austrais deste tipo de vegetação.

Foram analisadas exsicatas dos herbários EFC, FUEL, HFC, HUM, MBM, UPCB (no Paraná), além de HBR, R, RB e SP (siglas conforme Holmgren \& Holmgren 1998). Espécies com grande quantidade de coletas tiveram seus espécimes selecionados (um por município) e citados como tal. Uma lista completa com todas as coletas analisadas está disponível com os autores. A autoria das espécies e abreviatura dos autores das espécies seguiu dados do IPNI (2008).

Para análise do padrão de venação, morfologia das folhas, tépalas e anteras, bem como para a morfologia de ápice e base de folhas foi utilizado o trabalho de Ribeiro et al. (1999). Para o indumento foi utilizado Lawrence
(1951), para inflorescências Judd et al. (1999) e para estaminódios Rohwer (1993a). Medidas de estruturas vegetativas e reprodutivas foram tomadas com paquímetro, a partir de material não hidratado. Os dados de distribuição geográfica das espécies em nível nacional e mundial foram obtidos a partir de Baitello (2003), Moraes (2005), Moraes \& Oliveira (2007) e Rohwer (1993a). Os dados de distribuição no Estado foram obtidos a partir das exsicatas.

\section{Resultados e discussão}

A Floresta Ombrófila Mista e a Floresta Ombrófila Densa são as regiões fitogeográficas que apresentam maior número de espécies (nove), seguidas pela Floresta Estacional (sete). No Cerrado apenas uma espécie foi registrada, Nectandra lanceolata. Quatro espécies são exclusivas da Floresta Estacional, Nectandra angustifolia, $N$. cissiflora, $N$. cuspidata e $N$. hihua. Uma espécie é exclusiva da Floresta Ombrófila Densa, N. membranacea. As demais se encontram representadas em pelo menos duas das fitorregiões citadas. Nectandra hihua foi citada pela primeira vez para o Estado.

Nectandra Rol. ex Rottb. in Acta Lit. Univ. Hafn. 1: 279. 1778, nom. cons.

Nectandra sanguinea Rol. ex Rottb. in Acta Lit. Univ. Hafn. 1: 279. 1778.

Árvores ou arbustos. Folhas alternas, subopostas ou mais raro opostas, peninérveas, glabras ou pilosas. Inflorescências tirsóide-paniculadas, raramente botrióides. Flores andróginas, 3-17 mm diâm., seis tépalas, iguais a subiguais, unidas na base ou aparentemente livres, em geral densamente papilosas na face interna. Nove estames férteis, dispostos em três séries, sésseis ou com filetes distintos, os seis externos (séries I e II) mais ou menos iguais, algumas vezes ligeiramente adnatos às tépalas, introrsos, os três internos diferentes dos primeiros, extrorsos ou latrorsos, com um par de glândulas nectaríferas na base. Anteras tetraloceladas, locelos arranjados em arco aberto, raramente quase em dois pares, um acima do outro, com deiscência valvar. Três estaminódios, raramente ausentes, usualmente distintos, base frequentemente unida com os estames internos. Receptáculo raso ou profundamente urceolado, internamente glabro ou piloso. Ovário livre ou completamente envolvido pelo receptáculo, unilocular, com um único óvulo pêndulo. Fruto baga ou drupa, normalmente negro ou marrom quando maduro, parcial ou totalmente encoberto por uma cúpula geralmente avermelhada (Rohwer 1993a). 


\section{Chave para as espécies de Nectandra do Estado do Paraná}

1. Folhas adultas glabras a esparso-pilosas (puberulentas, seríceas, pubescentes ou esparsamente vilosas) na face abaxial

2. Ápice das folhas curto-cuspidado a cuspidado, folhas coriáceas

3. Flores entre 3-5 mm diâm., anteras das séries I e II com ápice papiloso-viloso, truncado ou arredondado, os filetes com 10 a $20 \%$ do compr. das anteras

2. N. cissiflora

3. Flores entre 6-8 mm diâm., anteras das séries I e II com ápice papiloso-puberulento, agudo, desprovidas de filete 4. N. grandiflora

2. Ápice das folhas acuminado a caudado, folhas cartáceas ou membranáceas

4. Folhas lineares, no máximo $1,5 \mathrm{~cm}$ larg. 1. N. angustifolia

4. Folhas elípticas, lanceoladas, oblanceoladas ou obovadas, acima de 1,6 cm larg.

5. Nervuras secundárias da face abaxial subsalientes a impressas

5. Nervuras secundárias da face abaxial salientes

6. Anteras das séries I e II com ápice truncado, filetes dos estames da série III iguais ou mais longos que as anteras 9. N. membranacea

6. Anteras das séries I e II com ápice agudo ou obtuso, filetes dos estames da série III menores que as anteras

7. Estilete até $10 \%$ do compr. do ovário 5. N. hihua

7. Estilete maior que $40 \%$ do compr. do ovário 2

8. Flores com $8 \mathrm{~mm}$ diâm. ou mais

9. Receptáculo externamente piloso-tomentoso 7. N. leucantha

9. Receptáculo externamente piloso-lanoso ou velutino

10. Ovário globoso, estilete com 40-50\% do compr. do ovário, base das folhas atenuada, aguda ou cuneada 6. N. lanceolata

10. Ovário elipsóide, estilete igual ao comprimento do ovário ou maior, base das folhas auriculadas, as aurículas dobrando-se sobre a face abaxial

4. N. reticulata

8. Flores com menos de $8 \mathrm{~mm}$ diâm.

11. Face abaxial das folhas apresentando tufos de pêlos na axila de nervuras secundárias basais

12. Anteras das séries I e II totalmente papiloso- puberulentas ........12. N. paranaensis

12. Anteras das séries I e II totalmente glabras ou glabras com ápice papiloso-puberulento

13. N. puberula

11. Face abaxial das folhas não apresentando tufos de pêlos na axila de nervuras secundárias basais 9. N. nitidula

1. Folhas adultas denso-pilosas (tomentosas, velutinas, lanosas) na face abaxial

13. Base das folhas auriculada, as aurículas dobrando-se sobre a face abaxial 14. N. reticulata

13. Base das folhas atenuada, aguda ou cuneada

14. Folhas opostas no ápice dos râmulos

14. Folhas alternas no ápice dos râmulos

15. Estames das séries I e II ovados a longamente ovados ou cordiformes, totalmente papiloso-tomentosos 6. N. lanceolata

15. Estames das séries I e II transverso-retangulares, totalmente papiloso-puberulentos a glabros com ápice papiloso-puberulento

3. N. cuspidata

1. Nectandra angustifolia Nees \& Mart. ex Nees, Linnaea 8: 48. 1833.

Fig. 1-3

Árvores 8-18 m. Folhas alternas nos ramos e ápice dos râmulos, lâmina 8-14×0,8-1,5 cm, linear, ápice acuminado a caudado, base atenuada, cartácea, face adaxial glabra, nervuras impressas, face abaxial glabra, nervura primária saliente, secundárias impressas, sem tufos de pêlos axilares. Inflorescências na axila de folhas, pedúnculo 0,7-4 cm. Flores 4-6 mm diâm., receptáculo internamente glabro, externamente piloso-seríceo; tépalas externas piloso-seríceas na face abaxial, papiloso- 
puberulentas na face adaxial, as internas com triângulo basal piloso-seríceo na face abaxial, papiloso-puberulentas na face adaxial; anteras das séries I e II transversoretangulares ou sub-orbiculares com ápice truncado ou agudo, totalmente papiloso-puberulentas ou glabras com ápice papiloso-puberulento, filetes $0-25 \%$ do compr. das anteras, na série III retangulares com ápice truncado, glabras com ápice papiloso-puberulento, filetes com 10-30\% do compr. das anteras, glândulas globosas, estaminódios clavados; ovário subgloboso a globoso, estilete com $25-100 \%$ do compr. do ovário. Fruto elipsóide, 12-15×8-10 mm, com cúpula basal.

Material selecionado: BRASIL. Paraná: Icaraíma, 21/IV/1968, G. Hatschbach \& O. Guimarães 19072 (MBM, RB, UPCB); Loanda, 8/IV/1959, G. Hatschbach 5601 (MBM); Porto Rico, 31/III/1989, A.O.S. Vieira et al. 426 (FUEL); São Jorge do Patrocínio, 11/XI/2002, C. Kozera et al. (MBM 284517); Vila Alta, 24/I/2003, C. Kozera 1831 (MBM).

Distribuição e ecologia: encontrada no Paraguai, Argentina, Uruguai e Brasil, onde ocorre nos Estados da BA, MS, SP, SC, PR e RS. No Paraná foi coletada apenas em FE, ao longo do curso de rios. Coletada com flores de janeiro a abril e com frutos de novembro a janeiro e em abril.

Nectandra angustifolia pode ser reconhecida pelas folhas estreitas, lineares, raramente alcançando $1,5 \mathrm{~cm}$ de largura, além das nervuras secundárias em ambas as faces serem impressas e obsoletas. É possível que a largura das folhas seja uma adaptação a períodos de inundação que a espécie, ribeirinha, enfrenta (Rohwer 1993a).

2. Nectandra cissiflora Nees, Syst. laur. 296. 1836.

Fig. 4-6

Árvores 5-18 m. Folhas alternas ou raramente subopostas nos ramos e ápice dos râmulos, lâmina 10-18×4-9,5 cm, obovada ou elíptica, ápice curtocuspidado, base atenuada ou cuneada, coriácea, face adaxial glabra, raramente piloso-pubescente, nervura primária e secundárias impressas, face abaxial glabra ou pilosa - pubescente ou esparsamente vilosa, nervura primária e secundárias salientes, sem tufos de pêlos axilares. Inflorescências na axila de catafilos ou folhas, pedúnculo 5-9,5 cm. Flores 3-5 mm diâm., receptáculo internamente glabro, externamente piloso-pubescente; tépalas externas piloso-pubescentes na face abaxial, papiloso - tomentosas ou vilosas na face adaxial, as internas com triângulo basal glabro ou piloso-pubescente na face abaxial, papiloso-tomentosas ou vilosas na face adaxial; anteras das séries I e II quadradas ou tranversoretangulares com ápice truncado ou arredondado, papiloso-puberulentas com ápice papiloso-viloso, filetes com $10-20 \%$ do compr. das anteras, na série III retangulares com ápice truncado, totalmente papilosopuberulentas, filetes com 10-20\% do compr. das anteras, glândulas globosas, estaminódios clavados; ovário globoso, estilete com 0-50\% do compr. do ovário. Fruto elipsóide, 12-16×8-9 mm, com cúpula basal.

Material selecionado: BRASIL. Paraná: Diamante do Norte, 6/IX/1998, J.M. Silva et al. 2499 (MBM); Icaraíma, 8/VIII/1967, G. Hatschbach 17047 (MBM); Porto Rico, 15/X/1998, M.V. Ferrari Tomé 1264 (MBM).

Material adicional: BRASIL. São Paulo: Paulo de Faria, X/1994, V.C. Souza et al. 12316 (FUEL); São José do Rio Preto, 20/XI/2002, M.A. Carreira-Lopes \& A.P. Oliveira (FUEL 34339).

Distribuição e ecologia: encontrada desde o Sul do México, países da América Central, porção Noroeste e Nordeste da América do Sul e no Brasil, onde ocorre nos Estados do AM, PA, AC, TO, PE, BA, GO, MT, MS, MG, SP, PR e RS. No Paraná, a espécie foi coletada apenas em FE. Coletada com flores de agosto a outubro e com frutos imaturos em outubro.

Nectandra cissiflora apresenta como características marcantes a face adaxial das tépalas e o ápice das anteras das séries I e II papiloso-vilosos (papilas longas e curvadas), um tipo peculiar de indumento não encontrado nas demais espécies. É também reconhecida pelas inflorescências longas e folhas coriáceas, com ápice curto-cuspidado.

3. Nectandra cuspidata Nees \& Mart. ex Nees, Syst. laur. 330. 1836.

Fig. 7-8

Árvores 5-9 m. Folhas alternas nos ramos e ápice dos râmulos, lâmina 10-17×2,4-5 cm, lanceolada ou elíptica, ápice caudado, base atenuada, cartácea, face adaxial glabra, nervura primária e secundárias impressas, face abaxial piloso-tomentosa, nervura primária e secundárias salientes, sem tufos de pêlos axilares. Inflorescências na axila de folhas, pedúnculo 1,7-4,5 cm. Flores 3-4 mm diâm., receptáculo internamente glabro ou piloso-seríceo no fundo, externamente piloso-seríceo; tépalas externas piloso-tomentosas a seríceas na face abaxial, glabras a papiloso-tomentosas na face adaxial, as internas com triângulo basal piloso-seríceo a tomentoso na face abaxial, papiloso-tomentosas na face adaxial; anteras das séries I e II tranverso-retangulares com ápice truncado ou arredondado, totalmente papilosopuberulentas ou glabras com ápice papiloso-puberulento, filetes com 10-50\% do compr. das anteras, na série III retangulares a quadradas com ápice truncado, totalmente papiloso-puberulentas ou glabras com ápice papilosopuberulento, filetes com 50-80\% do compr. das anteras, glândulas globosas, estaminódios clavados; ovário 
globoso, estilete maior que o compr. do ovário. Fruto subgloboso a elíptico, 8-14×6-10 mm, com cúpula basal (Rohwer 1993a).

Material selecionado: BRASIL. Paraná: Cianorte, 7/IX/1983, Y.S. Kuniyoshi \& C. Roderjan 4696 (MBM); Diamante do Norte, 27/IV/2002, C.I.L.F. Rosa et al. 222 (HUM); Loanda, 21/III/1986, U. Pastore \& R.M. Klein 50 (MBM); Próximo de São Manoel, 27/I/1982, P.P. Furtado 137 (RB).

Distribuição e ecologia: encontrada desde o extremo sul do México, América Central e porções Norte e Nordeste da América do Sul. No Brasil, apresenta distribuição abrangente, ocorrendo nos Estados do AC, AM, MA, PA, RO, RR, CE, PE, BA, MT, MS, GO e PR. Neste último Estado foi coletada apenas em FE. Coletada com flores de janeiro a julho e com frutos imaturos em setembro.

Nectandra cuspidata é muito semelhante a $N$. membranacea. No entanto, a superfície abaxial das folhas na primeira é piloso-tomentosa e na segunda esparso-serícea a glabra. Também em $N$. cuspidata os filetes dos estames da série III são mais curtos que as anteras, e em $N$. membranacea os filetes dos estames da série III são iguais a mais longos que as anteras.

4. Nectandra grandiflora Nees \& Mart. ex Nees, Linnaea 8: 49. 1833.

Fig. 9-11

Árvore 1,5-12 m. Folhas alternas nos ramos e ápice dos râmulos, lâmina 7,7-11×3,0-4,5 cm, obovada ou raramente elíptica, ápice curto-cuspidado a cuspidado, base atenuada a aguda, coriácea, face adaxial glabra, nervura primária sulcada ou impressa, secundárias impressas, face abaxial glabra, nervura primária e secundárias salientes, sem tufos de pêlos axilares. Inflorescências na axila de catafilos ou logo abaixo, acima da inserção do primeiro nó foliar, raramente na axila de folhas normais, pedúnculo 1,3-5,5 cm. Flores 6-8 mm diâm., receptáculo internamente e externamente glabro; tépalas externas glabras na face abaxial, papiloso-tomentosas na face adaxial, as internas com triângulo basal glabro na face abaxial, papilosotomentosas na face adaxial; anteras das séries I e II quadradas, trasnverso-retangulares ou largamente triangulares com ápice agudo, totalmente papilosopuberulentas, filetes ausentes, na série III retangulares com ápice truncado, totalmente papiloso-puberulentas, filetes com $0-20 \%$ do compr. das anteras, glândulas globosas, estaminódios clavados; ovário globoso, estilete com $10-20 \%$ do compr. do ovário. Fruto elipsóide, 15-18×10-11 mm, com cúpula basal.

Material selecionado: BRASIL. Paraná: Balsa Nova, 12/IX/1968, G. Hatschbach 19717 (MBM, RB); Bocaiúva do Sul, Ouro Fino, 5/X/1961, G. Hatschbach 8335 (MBM, RB, UPCB); Bocaiúva do Sul, 31/XII/1960, G. Hatschbach 7598 (MBM, RB); Castro, 3/X/1964, G. Hatschbach 11683 (MBM, RB); Clevelândia, 15/I/1983, J.R. Pirani et al. 435 (SP); Colombo, 22/I/2004, R.F.S. Possette \& O.S. Ribas (HFC 6512, MBM 298212); Curitiba, I/1991, S.D. Arruda (EFC); Fernandes Pinheiro, IX/1949, E.S. Araújo (R 28543); Fluviópolis, 9/III/1929, Gurgel 14659 (R, RB); Foz do Iguaçu, 10/X/1986, Negrelle et al. 100 (MBM, UPCB); Imbituva, 30/VII/1998, L.R.M. Souza et al. (FUEL 22210); Indaiatuba, 2/VIII/1998, J. Carneiro (MBM 234470); Ipiranga, 8/X/1969, G. Hatschbach 22375 (MBM); Irati, 31/VIII/1972, P.E. Carvalho 1 (HFC); Lapa, 24/IX/1976, G. Hatschbach 38883 (MBM); Mariópolis, 15/XII/1966, G. Hatschbach 15512 (MBM, RB); Marmeleiro, 10/V/1966, J.C. Lindeman \& J.H. Haas 1282 (RB); Morretes, 7/V/1981, L.T. Dombrowski 12772 (MBM); Palmeira, 13/XI/1963, R. Klein 4609 (HBR, RB); Pato Branco, 7/XII/1995, S.R. Ziller \& W. Maschio 1049 (MBM); Piraí do Sul, 9/X/1958, G. Hatschbach 5101 (MBM, RB, UPCB); Ponta Grossa, 13/X/2006, M.M.F. Zanon \& L. Grokoviski 40 (UPCB); Porto Amazonas, 17/IX/1950, G. Hatschbach 2000 (MBM); Reserva, 26/VIII/1997, M.R.C. Paiva et al. (FUEL 21390); São João do Triunfo, 25/X/1985, R. Seitz 4 (EFC); São José dos Pinhais, 15/VIII/1951, G. Hatschbach 2473 (MBM); Serrinha, 14/I/1904, Dusén 2697 (R); Teixeira Soares, 14/I/1994, L.H. Soares e Silva et al. 335 (FUEL); Teixeira Soares, 9/X/1979, E. Rotta 104 (HFC, HUM, MBM); Telêmaco Borba, 16/X/1999, A.O.S. Vieira (FUEL 30472); Tibagi, 13/IX/1996, Y.S. Kuniyoshi \& F. Galvão 5003 (MBM); Tijucas do Sul, 15/VI/1975, R. Kummrow 887 (MBM); Tunas, 11/IX/1997, J.M. Silva et al. 1958 (MBM, UPCB); União da Vitória, sem data, G. Koczicki 261 (MBM).

Distribuição e ecologia: espécie registrada no Uruguai e Brasil, onde ocorre nos Estados de MG, SP, PR, SC e RS. No Paraná, foi coletada em FOM e, com menos frequência, em FOD. Coletada com flores de maio a dezembro, e frutos de outubro a julho.

Nesta espécie as inflorescências estão dispostas quase que exclusivamente na axila de catafilos terminais ou logo abaixo, acima da inserção do primeiro nó foliar. Exceções a este padrão foram observadas em seis espécimes, onde a(s) inflorescência(s) estão dispostas na axila de folhas normais. Aliado a isto, as inflorescências, folhas e superfície externa do receptáculo são glabras, constituindo-se em importantes características para identificação. Além disso, $N$. grandiflora apresenta madeira com cheiro fortemente adocicado e desagradável, porém sem o odor de excremento presente em algumas Lauraceae. 
5. Nectandra hihua (Ruiz \& Pav.) Rohwer, Fl. Neotrop., Monogr. 60: 196. 1993.

Fig. 12-14

Árvore $12 \mathrm{~m}$. Folhas alternas nos ramos e ápice dos râmulos, lâmina 9-16×3,0-6 cm, elíptica, ápice acuminado, base atenuada a aguda, cartácea, face adaxial glabra, nervuras impressas, face abaxial glabra, nervura primária e secundárias salientes, tufos de pêlos axilares presentes ou não. Inflorescências na axila de folhas ou raramente na axila de catafilos, pedúnculo 2,3-6,5 cm. Flores 5-10 mm diâm., receptáculo internamente pilososeríceo ou velutino, externamente piloso-puberulento a seríceo; tépalas externas piloso-puberulentas a seríceas na face abaxial, com triângulo basal papiloso-tomentoso na face adaxial, as internas papiloso-puberulentas com triângulo basal piloso-seríceo na face abaxial, papilosotomentosas na face adaxial; anteras das séries I e II quadradas ou triangulares com ápice obtuso, totalmente papiloso-puberulentas, filetes com $0-10 \%$ do compr. das anteras, na série III retangulares com ápice truncado, totalmente papiloso-puberulentas, filetes ausentes, glândulas globosas, estaminódios clavados; ovário globoso, estilete com 0-10\% do compr. do ovário. Fruto elíptico a globoso, 9-13×9-11 mm, com cúpula basal (Rohwer 1993a).

Material examinado: BRASIL. Paraná: Altônia, 21/VI/1966, H. Lindeman \& H. de Haas 1666 (MBM, RB, SP); Guaíra, 11/VI/1980, E. Buttura (MBM 73486).

Distribuição e ecologia: ocorre desde o Oeste do México, América Central, Antilhas e América do Sul, até o Paraguai. No Brasil, foi encontrada nos Estados do AM, PA, AC, TO, AP, GO, MT, MS, MG, SP e PR. Neste último Estado foi coletada apenas em FE, com flores em junho.

Nectandra hihua é citada pela primeira vez para o Estado, coletada próximo às fronteiras com o Mato Grosso do Sul e Paraguai, onde aparentemente é comum. Pode ser confundida com $N$. leucantha que, segundo Rohwer (1993a), pode ser apenas uma variedade local de $N$. hihua. No entanto, $N$. hihua possui anteras das séries I e II quadradas ou triangulares e estilete curto, até $10 \%$ do comprimento do ovário, ao passo que em $N$. leucantha, as anteras das séries I e II são longamente ovadas a largamente triangulares e os estiletes são mais longos, de 50-100\% do comprimento do ovário.

\section{Nectandra lanceolata Nees \& Mart. ex Nees, Linnaea}

8: 47.1833.

Fig. 15-16

Árvore 3-20 m. Folhas alternas nos ramos e ápice dos râmulos, lâmina 7-15,5×1,8-4,8 cm, oblanceolada, elíptica ou estreito-elíptica, ápice acuminado a caudado, base atenuada, aguda ou cuneada, cartácea, face adaxial glabra, nervura primária sulcada, secundárias impressas, face abaxial piloso - tomentosa a velutina, raramente glabra, nervura primária e secundárias salientes, tufos de pêlos axilares presentes ou não. Inflorescências na axila de folhas ou raramente na axila de catafilos, pedúnculo 3,2-9,0 cm. Flores 9-14 mm diâm., receptáculo internamente glabro ou piloso-seríceo ao fundo, raramente piloso-lanoso, externamente pilosolanoso; tépalas externas piloso-lanosas na face abaxial, papiloso-tomentosas na face adaxial, as internas com triângulo basal piloso-lanoso na face abaxial, papilosotomentosas na face adaxial; anteras das séries I e II ovadas, longamente ovadas ou cordiformes com ápice obtuso, totalmente papiloso-tomentosas, filetes com 0-10\% do compr. das anteras, na série III retangulares com ápice truncado, totalmente papiloso-tomentosas, filetes com $0-10 \%$ do compr. das anteras, glândulas globosas, estaminódios clavados; ovário globoso, estilete com $40-50 \%$ do compr. do ovário. Fruto elipsóide, 15-18×13-16 mm, com cúpula basal.

Material selecionado: BRASIL. Paraná: Altônia, 22/X/1995, S.R. Ziller 992 (HFC, HUM, MBM); Apucarana, 17/XI/1999, O.C. Pavão et al. (FUEL 27470); Arapoti, 10/IX/1960, G. Hatschbach 7203 (RB); Bituruna, 18/XI/2004, D. Liebsch 954 (HFC, UPCB); Boa Vista da Aparecida, 18/XI/1998, A. Soares \& W. Maschio 305 (HFC); Califórnia, 19/X/2000, O.C. Pavão \& J.A. Ferreira (FUEL 30478, HFC 5524); Cambé, 26/IX/1997, V.F. Kinupp et al. 850 (FUEL); Campo, 17/X/1976, J. Marques 1 (RB); Campo Mourão, 13/X/1965, G. Hatschbach 12965 (MBM, RB); Cascavel, 18/X/1988, J. da Cruz 193 (UPCB); Castro, 14/XI/2000, J. Carneiro 808 (HFC, MBM, UPCB); Cerro Azul, 6/X/1960, G. Hatschbach 7301 (RB); Clevelândia, 22/XI/1972, G. Hatschbach 30831 (UPCB); Colombo, 7/XII/1984, A.M. Souza 105 (FUEL, HUM, RB); Curitiba, XI/2005, M.M.F. Zanon \& R. Goldenberg 29 (UPCB); Curiúva, 16/X/1999, R.A. Viani \& J. Baitello 17 (FUEL); Deodoro, 25/XII/1943, G. Hatschbach 80 (RB); Dorizon Mallet, 12/III/1929, Gurgel 14656 (R); Enéas Marques, 11/X/1974, G. Hatschbach 35148 (UPCB); Faxinal, 11/X/1965, G. Hatschbach 12916 (RB, UPCB); Fênix, 30/X/1998, J.M. Silva et al. 2565 (MBM); Foz do Iguaçu, 7/V/1949, J. Falcão 152 (RB); Guarapuava, 22/X/1960, G. Hatschbach 7353 (RB); Irati, 14/XI/1972, P.E. Carvalho 52 (HFC). Jaguariaíva, 15/X/1966, J.C. Lindeman \& J.H. Haas 3023 (RB); Londrina, 19/XI/1992, F.C. Silva 1602 (FUEL, R); Mandirituba, 17/X/2006, M.M.F. Zanon 43 (UPCB); Maringá, 25/X/1984, J. Maria (UPCB 13029); Medianeira, 19/XI/1966, J.C. Lindeman \& J.H. Haas 3310 (MBM); Pato Branco, 17/XI/1991, H. Lorenzi (SP 262237); Pinhão, 24/II/1996, G. Hatschbach et al. 64524 

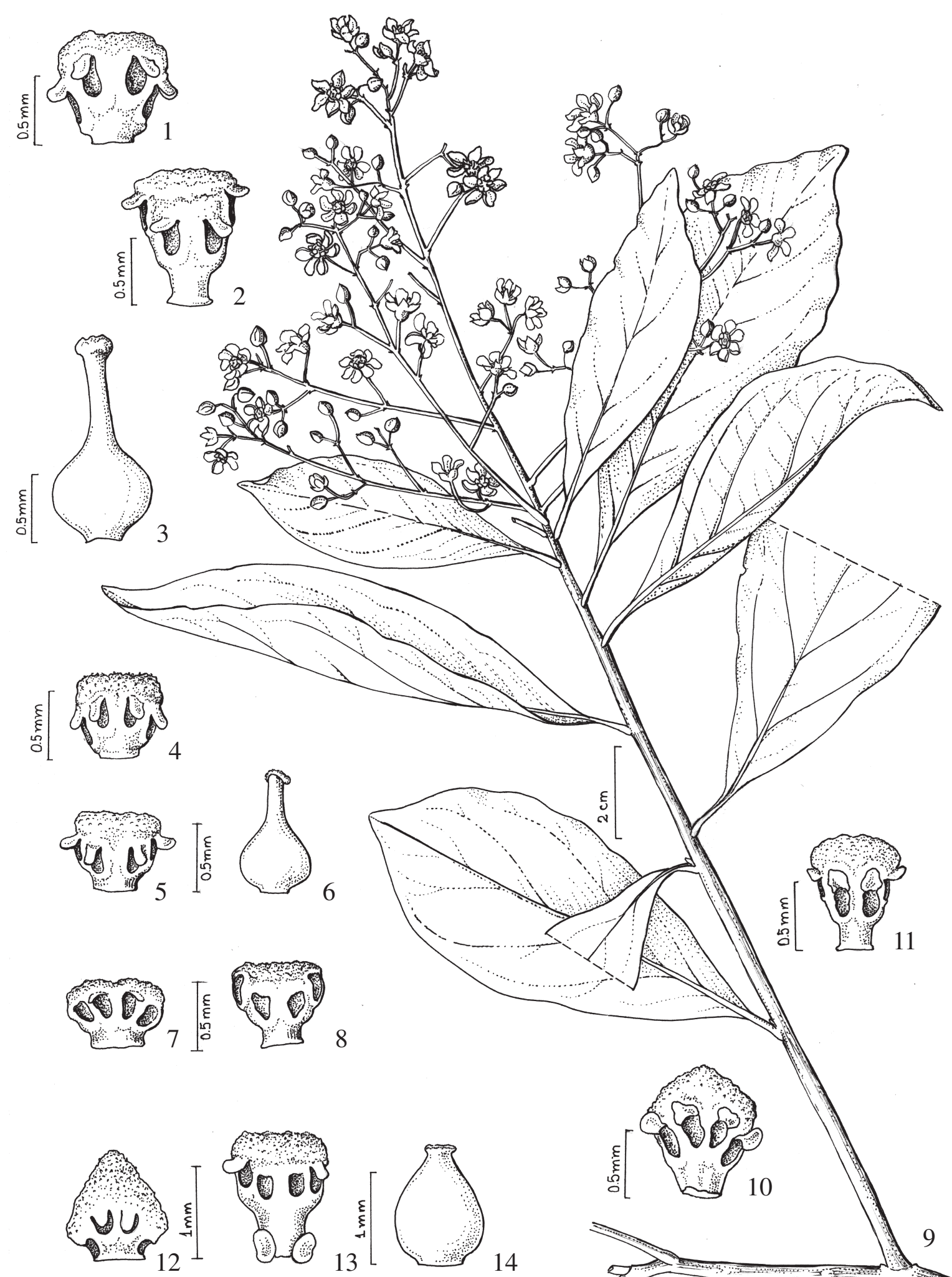

14 
(EFC, MBM); Piraquara, 17/XI/1960, G. Hatschbach 7437 (MBM, RB, UPCB); Pitanga, 13/XII/1973, G. Hatschbach 33516 (UPCB); Ponta Grossa, 13/X/2006, M.M.F. Zanon \& L. Grokoviski 41 (UPCB); Prudentópolis, 5/XI/1963, E. Pereira \& G. Hatschbach 7673 (RB); Quedas do Iguaçu, 14/X/1997, J.M. Silva et al. 2082 (MBM); Reserva, 10/XI/1998, J.A. Ferreira et al. (FUEL 30479, HFC 5523); Rio Branco do Sul, 9/XI/1999, J.M. Cruz \& J. Cordeiro 200 (MBM); Rolândia, 25/II/1937, G. Tessmann 81 (RB); São Jerônimo da Serra, 21/X/2002, E.M. Francisco (FUEL 34700); São João do Triunfo, 8/XI/1967, G. Hatschbach 17788 (RB); São Mateus do Sul, 1/XI/1985, R.M. Britez 220 (HFC, UPCB); São Miguel do Iguaçu, 22/X/1969, G. Hatschbach 22604 (UPCB); Sapopema, 10/X/1998, C. Medri et al. 723 (FUEL); Tamarana, 1/XI/2000, E.M. Francisco et al. (FUEL 30476, HUM 8261); Telêmaco Borba, 28/X/1997, R. Kersten \& S.M. Silva 239 (UPCB); Terra Roxa, 31/X/1986, Pastore \& R.M. Klein 174 (RB); Tibagi, 27/X/1995, N.V. Rosa et al. (FUEL 17447, HFC 5677); Tijucas do Sul, 4/XI/1988, R. Kummrow et al. 3086 (UPCB); Três Barras do Paraná, 5/X/1997, I. Isernhagen \& M. Borgo 145 (UPCB); Virmond, 17/XI/1998, G. Hatschbach et al. 68766 (UPCB).

Distribuição e ecologia: espécie ocorrente na Argentina, Paraguai e no Brasil, onde ocorre nos Estados de MG, RJ, SP, PR, SC e RS. No Paraná foi coletada em FE, CE e em FOM. Coletada com flores de agosto a dezembro e com frutos de outubro a março.

Apresenta as maiores flores dentre as espécies paranaenses (9-14 mm de diâmetro), com perigônio de cor creme e perfume adocicado em material fresco.

7. Nectandra leucantha Nees \& Mart. ex Nees, Linnaea 8: 48.1833.

Fig. 17-21

Árvore 5-10 m. Folhas alternas nos ramos e ápice dos râmulos, lâmina 13,5-25×5-11,5 cm, obovada ou elíptica, ápice acuminado, base cuneada, cartácea ou membranácea, face adaxial glabra, nervura primária impressa, raramente sulcada, secundárias impressas, face abaxial glabra, nervura primária e secundárias salientes, tufos de pêlos axilares presentes. Inflorescências na axila de folhas, pedúnculo 1,6-11 cm. Flores 8-11 mm diâm., receptáculo internamente glabro, externamente pilosotomentoso; tépalas externas piloso-tomentosas na face abaxial, papiloso-tomentosas na face adaxial, as internas com triângulo basal piloso - seríceo ou tomentoso na face abaxial, papiloso-tomentosas na face adaxial; anteras das séries I e II longamente ovadas ou largamente triangulares com ápice obtuso, totalmente papilosotomentosas, filetes com $0-10 \%$ do compr. das anteras, na série III retangulares com ápice truncado ou obtuso, totalmente papiloso-tomentosas, filetes $10-20 \%$ do compr. das anteras, glândulas globosas, estaminódios clavados; ovário globoso, estilete com 50-100\% do compr. do ovário. Fruto elipsóide, 24-27×13-15 mm, com cúpula basal.

Material selecionado: BRASIL. Paraná: Adrianópolis, 22/V/1958, G. Hatschbach 4586 (MBM); Antonina, 26/IX/1966, G. Hatschbach 14752 (MBM, RB); Bocaiúva do Sul, 22/X/1956, G. Hatschbach 4588 (MBM, UPCB); Cerro Azul, 8/IV/1964, G. Hatschbach 11151 (MBM); Guaraqueçaba, 8/XI/1995, R.X. Lima 422 (UPCB); Morretes, 21/IV/1904, P. Dusén 4460 (R); Paranaguá, 22/IV/1967, G. Hatschbach 16358 (MBM, RB, UPCB).

Distribuição e ecologia: espécie ocorrente apenas no Brasil, onde ocorre nos Estados de MG, RJ, SP, PR e SC. No Paraná, foi coletada em FOM e, principalmente, em FOD. Coletada com flores de abril a junho e em outubro e frutos de setembro a novembro.

Esta é a espécie paranaense que apresenta a maior lâmina foliar, raramente menor que $16 \times 7 \mathrm{~cm}$. Seus ramos são geralmente negros e as flores possuem perigônio ferrugíneo em material desidratado. Ver comentários em N. hihua.

8. Nectandra megapotamica (Spreng.) Mez, Bull. Herb. Boissier, sér. 2, 3: 794. 1903.

Fig. 22-24

Árvore 3-15 m. Folhas alternas nos ramos e ápice dos râmulos, lâmina 6-15×1,6-3,5 cm, lanceolada ou elíptica, ápice acuminado a caudado, base atenuada, cartácea, face adaxial glabra, nervura primária fracamente saliente, secundárias impressas, face abaxial glabra, nervura primária saliente, secundárias impressas a sub-salientes, sem tufos de pêlos axilares. Inflorescências na axila de catafilos, raramente na axila de folhas, pedúnculo 0,5-3,6 cm. Flores 4-6 mm diâm., receptáculo internamente glabro, externamente pilososeríceo; tépalas externas piloso-seríceas na face abaxial, papiloso-puberulentas na face adaxial, as internas com triângulo basal piloso-seríceo na face abaxial, papilosopuberulentas na face adaxial; anteras das séries I e II quadradas, retangulares ou tranverso-retangulares com ápice truncado ou agudo, totalmente papilosopuberulentas ou glabras com ápice papiloso-puberulento, filetes com 10-40\% do compr. das anteras, na série III retangulares com ápice truncado, totalmente papilosopuberulentas ou glabras com ápice papiloso-puberulento, filetes com $25-50 \%$ do compr. das anteras, glândulas globosas, estaminódios clavados; ovário globoso, estilete com $50-70 \%$ do compr. do ovário. Fruto elipsóide, 10-12×7-8 mm, com cúpula basal.

Material selecionado: BRASIL. Paraná: Adrianópolis, 14/I/1999, J.M. Silva et al. 2841 (MBM); 
Apucarana, 21/VIII/1997, D. Saraiva et al. (FUEL 21396, HFC 4839); Arapongas, 5/IX/1997, C.A. Avanzi et al. (FUEL 24706); Assaí, 7/XII/1997, S.R. Ziller \& W. Maschio 1672 (EFC, HFC); Bandeirantes, 1/VIII/1997, A. Petenacci 1143 (FUEL); Barra de São Tomé, 24/VII/1967, G. Hatschbach 16974 (RB); Bela Vista do Paraíso, 18/VIII/1999, J.A. Ferreira et al. (FUEL 25713); Bocaiúva do Sul, 10/VII/1960, G. Hatschbach 7132 (RB); Cambé, 22/VIII/1997, V.F. Kinupp et al. 813 (FUEL); Campina Grande do Sul, 15/VIII/1985, J. Cordeiro \& J.M. Silva 99 (RB, UPCB); Campo do Tenente, 25/II/1994, P.E. Carvalho 294 (HFC); Cascavel, 21/X/1988, N.I. Morosini 2 (FUEL); Cerro Azul, 17/VIII/1984, G. Hatschbach 48081 (R); Cianorte, 21/III/1966, J.C. Lindeman \& J.H. Haas 677 (RB); Colombo, 13/XI/1984, P.E. Carvalho 77 (HUM); Congonhinhas, 10/II/1999, E.M. Francisco \& J. Alves (FUEL 23768); Contenda, 3/VI/1958, G. Hatschbach 4946 (RB); Cornélio Procópio, 3/VIII/1995, A. Petenacci 468 (FUEL); Cruzeiro do Sul, 28/VIII/1999, J.M. Silva et al. 3019 (HFC, MBM); Curitiba, 22/IV/1996, V.A. Dittrich \& C. Kozera 98 (UPCB); Dois Vizinhos, 9/XII/1968, G. Hatschbach \& O. Guimarães 20585 (UPCB); Fênix, 26/VIII/1996, S.B. Mikich (UPCB 33569); Foz do Iguaçu, 6/XII/1992, S.A. Nicolau et al. 558 (SP); Guaraqueçaba, 28/II/1969, G. Hatschbach 21201 (MBM); Ibiporã, 3/VIII/1994, F. Chagas e Silva 1720 (FUEL, HFC); Icaraíma, 28/VII/1967, G. Hatschbach 17049 (RB); Itambaracá, 6/IX/1995, A. Petenacci 499 (FUEL); Ivaí, IX/1874, s.col. (R 30918); Jataizinho, 23/VIII/1998, A.L. Louzano et al. (FUEL 24704); Jundiaí do Sul, 10/X/2000, J. Carneiro 968 (MBM, RB); Laranjeiras do Sul, 22/IX/1968, G. Hatschbach 19796 (RB); Lobato, 18/VII/1962, J.C. Gomes \& Matos Filho 249 (RB); Londrina, 2/X/1985, C.E. Yamamoto et al. 19 (FUEL, HUM); Marilândia do Sul, 3/VIII/1999, J.A. Ferreira et al. (FUEL 25714, HFC 6057); Maringá, 30/VII/1987, L. Takahashi et al. (HUM 887); Monte Alegre, 4/VII/1960, A.P. Duarte \& G. Hatschbach 5268 (RB); Nova Fátima, 2/VII/1998, M.R.C. Paiva et al. (FUEL 23631); Nova Prata do Iguaçu, 8/VII/1997, I. Isernhagen \& M. Borgo 82 (UPCB); Ortigueira, 26/VIII/1997, M.R.C Paiva et al. (HFC 4879, UPCB 36160); Paranaí, 18/VII/1999, G. Hatschbach \& J.M. Silva 69256 (HFC, MBM); Primeiro de Maio, 17/VIII/1999, J.A. Ferreira et al. (FUEL 25711); Rancho Alegre, 24/VIII/1999, E.M. Francisco et al. (FUEL 26067); Reserva, 15/XII/1998, J.A. Ferreira et al. (RB 361756, UPCB 44117); Rio Branco, 6/X/1929, F.C. Hoehne (SP 24376); Rio Negro, 16/X/1957, G. Hatschbach 4171 (HBR, RB); Santa Amélia, 23/VIII/1998, D.A. Rinaldi \& M. Fuziki (FUEL 24705); Santa Mariana, 1/VIII/1995, V.T.O. 462 (FUEL);
Santo Antônio do Caiuá, 23/VI/1966, G. Hatschbach 14494 (RB); Santo Antônio do Paraíso, 9/XII/1997, L.R.M. Souza et al. (FUEL 20927); São Mateus do Sul, 24/III/1987, R.M. Britez et al. 1331 (UPCB); São Pedro do Ivaí, 13/XI/2003, O.S. Ribas et al. 5553 (UPCB); São Sebastião da Amoreira, 2/IX/1999, E.M. Francisco (FUEL 30489, HFC 5525, HUM 8260); Sapopema, 22/I/1998, V.F. Kinupp 984 (FUEL); Sertaneja, 12/XII/1997, L.R.M. Souza et al. (FUEL 21277, HFC 4883); Sertanópolis, 27/VIII/1986, E.A. Silva 18 (FUEL); Telêmaco Borba, 26/IX/1990, W. Zangaro Filho et al. (FUEL 11006); Tibagi, 4/VII/1960, G. Hatschbach \& A. Duarte 7117 (RB); Tomazina, 17/IX/1993, G. Hatschbach \& E. Barbosa 59370 (RB).

Distribuição e ecologia: espécie ocorrente na Argentina, Paraguai, Uruguai e no Brasil, onde ocorre nos Estados do MT, MS, MG, RJ, SP, PR, SC e RS. No Paraná, coletada em FE, FOM e, com menos frequência em FOD. Coletada com flores o ano todo e com frutos de setembro a maio.

Nectandra megapotamica é a espécie com menos caracteres diagnósticos dentre as espécies paranaenses e, por possuir, por vezes, locelos em arco quase fechado, podendo ser confundida até mesmo com Ocotea. Entre as Nectandra, assemelha-se a N. angustifolia, que também possui folhas glabras, sem tufos de pêlos axilares, porém lâmina mais estreita, de no máximo $1,5 \mathrm{~cm}$ larg. Também se parece com $N$. puberula, no entanto esta apresenta as nervuras secundárias da face abaxial evidentes, ao contrário de $N$. megapotamica que possui nervuras secundárias da face abaxial impressas a subsalientes, ficando a nervura central destacada na lâmina. Outro caráter que pode ser usado para diferenciação entre as duas é o fato de $N$. puberula sempre apresentar, na face abaxial das folhas, tufos de pêlos na axila de nervuras secundárias basais, enquanto que, em N. megapotamica, dos 192 materiais analisados, apenas um (A. Petenacci 1143) apresentou essa pilosidade.

9. Nectandra membranacea Griseb., Fl. Brit. W.I. 282. 1860.

Fig. 25-27

Árvore 5-16 m. Folhas alternas nos ramos e ápice dos râmulos, lâmina 9-19×2-6,3 cm, lanceolada ou elíptica, ápice caudado, base atenuada, cartácea ou membranácea, face adaxial glabra, nervura primária e secundárias impressas, face abaxial glabra a pilosopuberulenta ou esparsamente serícea, nervura primária e secundárias salientes, sem tufos de pêlos axilares. Inflorescências na axila de catafilos ou folhas, pedúnculo 2,0-3,6 cm. Flores 3-4 mm diâm., receptáculo internamente glabro, externamente piloso-seríceo; tépalas 
externas piloso-seríceas na face abaxial, papilosopuberulentas a tomentosas na face adaxial, as internas com triângulo basal piloso-seríceo na face abaxial, papiloso-puberulentas a tomentosas na face adaxial; anteras das séries I e II transverso-retangulares com ápice truncado, totalmente papiloso-puberulentas ou glabras com ápice papiloso-puberulento, filetes com 50-100\% do compr. das anteras, na série III quadradas com ápice truncado, totalmente papiloso-puberulentas ou glabras com ápice papiloso-puberulento, filetes iguais a $20 \%$ maiores que o compr. das anteras; glândulas globosas, estaminódios clavados; ovário globoso, estilete igual ao compr. do ovário. Fruto subgloboso, 10×9 mm, com cúpula recobrindo $1 / 2$ do fruto.

Material selecionado: BRASIL. Paraná: Antonina, 24/II/1997, G. Tiepolo \& G.R. Curcio 739 (EFC); Guaraqueçaba, 12/IV/1995, S.R. Ziller \& W. Maschio 788 (HFC, HUM); Morretes, 27/IX/2006, M.M.F. Zanon 37 (UPCB); Paranaguá, 2/III/1983, C.V. Roderjan 270 (MBM).

Distribuição e ecologia: espécie ocorrente desde o México, Antilhas, América Central e América do Sul até a Colômbia. No Brasil ocorre nos Estados de RO, TO, BA, MG, RJ, ES, SP, PR e SC. No Paraná, está restrita à FOD. Coletada com flores de novembro a junho e com frutos de janeiro a março e de junho a setembro.

Nectandra membranacea assemelha-se muito a $N$. cuspidata, mas dela difere pelo indumento da superfície abaxial das folhas e pelo comprimento dos filetes da série III. Ver comentários em $N$. cuspidata.

10. Nectandra nitidula Nees \& Mart. ex Nees, Linnaea 8: 48.1833.

Fig. 28-30

Árvore 6-8 m. Folhas alternas nos ramos e ápice dos râmulos, lâmina 8,0-10,5×3,0-3,7 cm, lanceolada ou elíptica, ápice acuminado, base atenuada, cartácea, face adaxial glabra, nervura primária e secundárias impressas, face abaxial glabra, nervura primária e secundárias salientes, sem tufos de pêlos axilares. Inflorescências na axila de catafilos ou folhas, pedúnculo 2,8-3 cm. Flores 5-6 mm diâm., receptáculo internamente glabro, externamente piloso-seríceo; tépalas externas glabras a piloso-puberulentas na face abaxial, papiloso-puberulentas a tomentosas na face adaxial, as internas com triângulo basal piloso-puberulento a seríceo na face abaxial, papiloso-puberulentas a tomentosas na face adaxial; anteras das séries I e II transversoretangulares com ápice obtuso, totalmente glabras, filetes com $0-10 \%$ do compr. das anteras, na série III retangulares com ápice obtuso, totalmente glabras, filetes com 0-10\% do compr. das anteras, glândulas globosas, estaminódios clavados; ovário globoso, estilete com
10-50\% do compr. do ovário. Fruto elipsóide, $11 \times 7 \mathrm{~mm}$, com cúpula basal (Rohwer 1993a).

Material examinado: BRASIL. Paraná: Adrianópolis, 8/X/1964, G. Hatschbach 11699 (MBM); Ponta Grossa, 17/I/1998, S. Ribas et al. 2315 (MBM).

Material adicional: BRASIL. São Paulo: Campinas, 15/IX/1994, A.P. Spina 307 (MBM).

Distribuição e ecologia: espécie restrita ao Brasil, onde ocorre nos Estados da BA, MG, SP e PR. Neste último Estado foi coletada em FOM e FOD. Coletada com flores em novembro e com frutos em janeiro.

Nectandra nitidula é a única espécie paranaense que sempre apresenta as anteras das três séries totalmente glabras. Rohwer e Kubitzki (1993) a colocaram como pertencente ao grupo $N$. grandiflora, no qual também estaria $N$. gardneri Meisn., embora reconheçam que as três espécies não apresentam muitas semelhanças em termos morfológicos, mas que possuem uma grande homogeneidade em termos ecológicos. Comparando-se as coleções paranaenses de $N$. grandiflora e $N$. nitidula foi possível observar que o único caráter compartilhado é a falta ou escassez de pilosidade nas partes vegetativas e reprodutivas, sendo bastante diferentes nas demais características.

11. Nectandra oppositifolia Nees \& Mart. ex Nees, Linnaea 8: 47. 1833.

Fig. 31-33

Árvore 5-21 m. Folhas opostas a subopostas, raramente alternas nos ramos, opostas no ápice dos râmulos, lâmina 8-30×2-10 cm, lanceolada, oblanceolada ou elíptica, ápice acuminado a subcaudado, base atenuada a aguda, face adaxial glabra a pilosopuberulenta, nervuras impressas, face abaxial pilosolanosa, nervura primária e secundárias salientes, sem tufos de pêlos axilares. Inflorescências na axila de folhas, pedúnculo 1,5-5 cm. Flores 7-11 mm diâm., receptáculo internamente glabro, externamente piloso-lanoso ou seríceo; tépalas externas piloso-lanosas na face abaxial, papiloso-tomentosas na face adaxial, as internas com triângulo basal piloso-seríceo ou lanoso na face abaxial, papiloso-tomentosas na face adaxial; anteras das séries I e II longamente ovadas ou triangulares com ápice obtuso, totalmente papiloso-tomentosas, filetes com 0-10\% do compr. das anteras, na série III ovadas ou retangulares com ápice obtuso, totalmente papilosotomentosas, filetes com $0-10 \%$ do compr. das anteras, glândulas globosas, estaminódios clavados; ovário subgloboso a globoso, estilete com 50-100\% do compr. do ovário. Fruto elipsóide, 15-17×10-11 mm, com cúpula envolvendo $1 / 3$ do fruto.

Material selecionado: BRASIL. Paraná: Antonina, 27/IX/2006, M.M.F. Zanon 38 (UPCB); Apucarana, 
10/IV/2000, E.M. Francisco et al. (RB 379389); Bocaiúva do Sul, 8/VII/1988, G. Hatschbach \& J.M. Silva 52138 (MBM, UPCB); Cerro Azul, 27/III/1981, G. Hatschbach 43683 (MBM); Curiúva, 24/XI/1999, O.C. Pavão \& E.M. Francisco (FUEL 30482, HFC 5529); Guaraqueçaba, 15/III/1984, Y.S. Kuniyoshi \& A. Pizani 4753 (EFC, MBM, RB, UPCB); Guaratuba, 29/III/1997, E.V. Odia \& J.M. Silva 109 (MBM); Jundiaí do Sul, 15/III/1996, J. Carneiro 206 (MBM); Matinhos, 18/X/2006, M.M.F. Zanon 44 (UPCB); Morretes, 28/IX/2006, M.M.F. Zanon 39 (UPCB); Paranaguá, 18/IV/1953, G. Hatschbach 3169 (HBR, RB); Rio Branco do Sul, 25/III/1986, J.M. Silva 108 (MBM); São José dos Pinhais, 29/XI/1975, H.G. Richter 45 (RB); Telêmaco Borba, 23/II/1995, S.A. Filipaki (UPCB 33141); Tunas do Paraná, 23/III/2001, J.M. Silva et al. 3356 (MBM, RB).

Distribuição e ecologia: espécie encontrada no Panamá, Equador, Bolívia, Colômbia e no Brasil, onde ocorre nos Estados do CE, BA, MG, ES, RJ, SP, PR, SC e RS. No Paraná foi coletada em FOD, FOM e, com menos frequência em FE. Coletada com flores de janeiro a julho e com frutos de março a novembro.

Nectandra oppositifolia pode ser reconhecida pela face abaxial da lâmina comumente ferrugínea e pela filotaxia, normalmente, oposta ou suboposta nos ramos, sempre oposta no ápice dos râmulos. É semelhante a $N$. reticulata, mas esta, no entanto, possui a base da lâmina cordada, com os lobos reflexos, e o receptáculo internamente piloso.

\section{Nectandra paranaensis Coe-Teix., Acta Amazonica} 5(2): 170. 1975.

Fig. 34-37

Árvore 5-10 m. Folhas alternas nos ramos e ápice dos râmulos, lâmina 10-15×3-4,5 cm, lanceolada ou elíptica, ápice acuminado a caudado, base atenuada a aguda, cartácea, face adaxial glabra, nervura primária e secundárias sulcadas, face abaxial glabra, nervura primária e secundárias salientes, tufos de pêlos axilares presentes. Inflorescências na axila de catafilos ou raramente na axila de folhas, pedúnculo $2-3,5 \mathrm{~cm}$. Flores 5-7 mm diâm., receptáculo internamente glabro, externamente piloso-seríceo; tépalas externas pilososeríceas na face abaxial, papiloso-tomentosas na face adaxial, as internas com triângulo basal piloso-seríceo na face abaxial, papiloso-tomentosas na face adaxial; anteras das séries I e II quadradas ou cordiformes com ápice obtuso, totalmente papiloso-puberulentas, filetes com $0-10 \%$ do compr. das anteras, na série III quadradas ou retangulares com ápice truncado, totalmente papilosopuberulentas ou raramente glabras com ápice papilosopuberulento, filetes com $0-50 \%$ do compr. das anteras, glândulas globosas, estaminódios clavados; ovário globoso, estilete com 50-80\% do compr. do ovário. Fruto sub-globoso, 20×14 mm, com cúpula basal.

Material selecionado: BRASIL. Paraná: Campina Grande do Sul, 15/VIII/1985, J. Cordeiro \& J.M. Silva 96 (MBM,UPCB); Morretes, 29/VII/1946, G. Hatschbach 336 (MBM, RB); São José dos Pinhais, 29/XI/1975, H.G. Richter 47 (RB).

Distribuição e ecologia: espécie de distribuição bastante restrita, só ocorrendo no Brasil nos Estados de SP e PR. Neste último Estado, ocorre em FOD e FOM. Coletada com flores de julho a setembro e com frutos em novembro.

Nectandra paranaensis possui as inflorescências na axila de catafilos, raramente na axila de folhas normais. Pode ser confundida com $N$. megapotamica, mas difere desta por apresentar as nervuras secundárias abaxiais salientes e com tufos de pêlos axilares. Também pode ser confundida $\operatorname{com} N$. puberula e $N$. membranacea, mas possui as flores maiores, normalmente entre $6-7 \mathrm{~mm}$ de diâmetro.

\section{Nectandra puberula Nees, Syst. laur. 332.1836.}

Fig. 38-40

Árvore 2,5-23 m. Folhas alternas nos ramos e ápice dos râmulos, lâmina 7,5-13×1,8-3,5 cm, lanceolada ou elíptica, ápice acuminado a caudado, base atenuada, cartácea, face adaxial glabra, nervura primária e secundárias sulcadas, face abaxial glabra, raramente piloso-puberulenta, nervura primária e secundárias salientes, tufos de pêlos axilares presentes. Inflorescências na axila de folhas, pedúnculo $1,5-4,5 \mathrm{~cm}$. Flores 4-6 mm diâm., receptáculo internamente glabro, externamente piloso-seríceo; tépalas externas piloso-seríceas a tomentosas na face abaxial, papiloso-puberulentas a tomentosas na face adaxial, as internas com triângulo basal piloso-seríceo a tomentoso na face abaxial, papiloso-puberulentas a tomentosas na face adaxial; anteras das séries I e II sub-orbiculares com ápice obtuso ou cordiformes com ápice agudo, totalmente glabras ou glabras com ápice papiloso-puberulento, filetes com 10-70\% do compr. das anteras, na série III retangulares com ápice truncado, glabras com ápice papilosopuberulento, filetes com 40-100\% do compr. das anteras; glândulas globosas, estaminódios subulados; ovário globoso, estilete igual ao compr. do ovário ou maiores. Fruto globoso, 11-13×9-10 mm, com cúpula basal.

Material selecionado: BRASIL. Paraná: Bocaiúva do Sul, 30/I/1996, O.S. Ribas et al. 1089 (MBM); Campina Grande do Sul, 9/IV/1967, G. Hatschbach 16277 (MBM, RB); Guaratuba, 31/X/2006, M.M.F. Zanon 45 (UPCB); Morretes, 27/IX/1986, Y.S. Kuniyoshi 5016 (EFC); Piraquara, I/2004, R. Goldenberg 

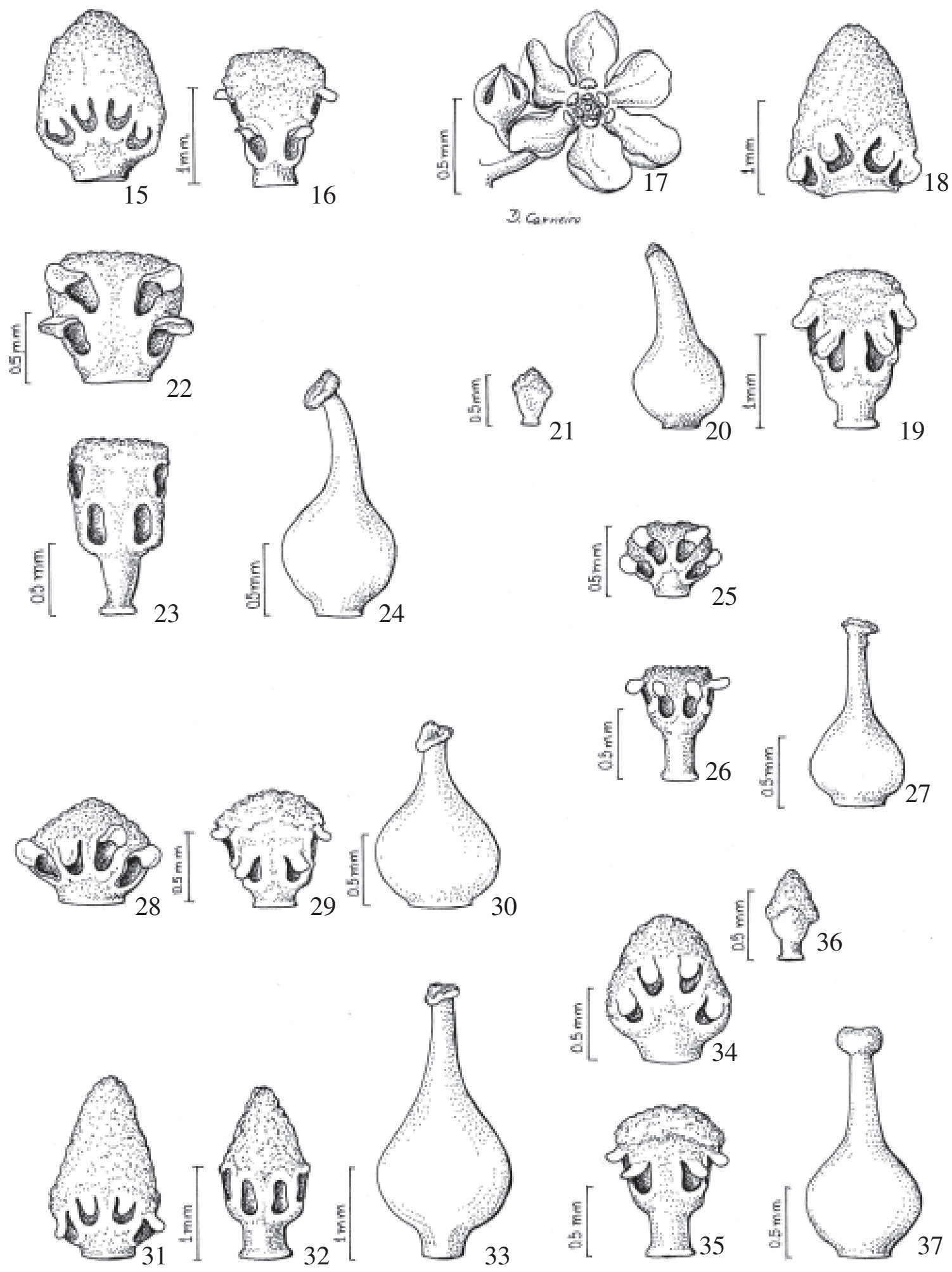

Figuras 15-37. 15-16. Nectandra lanceolata Nees \& Mart. ex Nees (Hatscgbach 19024). 15. Estame série II. 16. Estame série III. 7-21. N. leucantha Nees ex Mart. ex Nees (Hatscgbach 16358). 17. Flor. 18. Estame série II. 19. Estame série III. 20. Gineceu. 21. Estaminódio. 22-24. N. megapotamica (Spreng.) Mez (Cervi 2785). 22. Estame série II. 23. Estame série III. 24. Gineceu. 25-27. N. membranacea Griseb. (Roderjan 270). 25. Estame série II. 26. Estame série III. 27. Gineceu. 28-30. N. nitidula Nees \& Mart. ex Nees (Hatschbach 11699). 28. Estame série I. 29. Estame série III. 30. Gineceu. 31-33. N. oppositifolia Nees \& Mart. ex Nees (Hatschbach 52138). 31. Estame série I. 32. Estame série III. 33. Gineceu. 34-37. N. paranaensis Coe-Teix. (Cordeiro 96). 34. Estame série I. 35. Estame série III. 36. Estaminódio. 37. Gineceu. 
\& I.G. Varassin 619 (UPCB); Quatro Barras, 9/V/1990, J.M. Silva \& G. Hatschbach 853 (MBM, R); São José dos Pinhais, 20/III/1997, J. Cordeiro \& J.M. Cruz 1431 (MBM); Tijucas do Sul, 15/III/1962, G. Hatschbach 9045 (MBM, RB); Tunas do Paraná, 14/XII/1999, J.M. Silva \& L.M. Abe 3115 (MBM).

Distribuição e ecologia: espécie restrita ao Brasil, onde ocorre nos Estados da BA, MT, MG, DF, ES, RJ,
SP, PR e SC. No Paraná, está representada na FOD e FOM. Coletada com flores de janeiro a maio, setembro e dezembro e com frutos de junho a outubro.

Nectandra puberula pode ser confundida com $N$. lanceolata, mas desta difere por apresentar a superfície abaxial da lâmina foliar glabra ou esparsamente pilosa, enquanto em $N$. lanceolata a superfície abaxial da lâmina raramente é glabra, geralmente apresentando

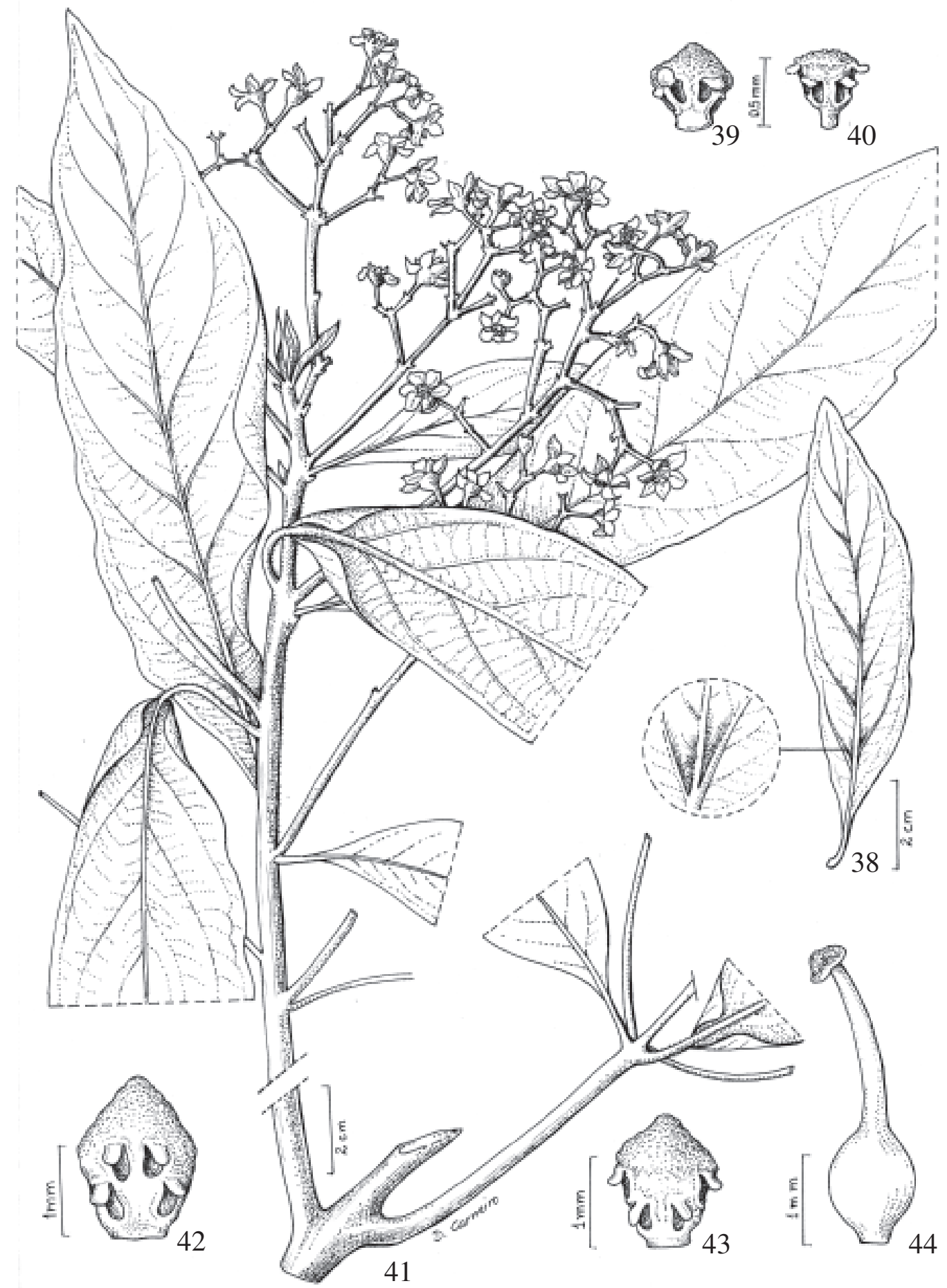

Figuras 38-44. 38-40. Nectandra puberula Nees (Hatschbach 9045). 38. Folha com tufos de pelos axilares. 39. Estame série I. 40. Estame série III. 4-44. N. reticulata Mez (Ribas 1938). 41. Ramos com flores. 42. Estame série II. 43. Estame série III. 44. Gineceu. 
indumento denso, tomentoso ou velutino. Ver comentários em $N$. paranaensis.

14. Nectandra reticulata Mez, Jahrb. Königl. Bot. Gart. Berl. 5: 404. 1889.

Fig. 41-44

Árvore 5-20 m. Folhas alternas ou raramente opostas nos ramos e ápice dos râmulos, lâmina 14-28x 4,5-8,5 cm, lanceolada ou elíptica, ápice caudado, raramente acuminado, base auriculada, aurículas dobradas sobre superfície abaxial, cartácea, face adaxial glabra ou piloso-velutina, nervuras impressas, face abaxial pilososerícea a velutina, nervura primária e secundárias salientes, sem tufos de pêlos axilares. Inflorescências na axila de folhas, pedúnculo 3,3-9 $\mathrm{cm}$. Flores $9-13 \mathrm{~mm}$ diâm., receptáculo internamente piloso-lanoso, externamente piloso-lanoso a velutino; tépalas externas pilosolanosas na face abaxial, piloso-tomentosas na face adaxial, as internas com triângulo basal piloso-lanoso na face abaxial, papiloso-tomentosas na face adaxial; anteras das séries I e II ovadas a longamente ovadas ou cordiformes com ápice obtuso a agudo, totalmente papilosotomentosas, filetes com $0-20 \%$ do compr. das anteras, na série III estreito-retangulares com ápice truncado ou agudo, totalmente papiloso-tomentosas, filetes com 0-10\% do compr. das anteras; glândulas globosas, estaminódios subulados; ovário elipsóide, estilete igual ao compr. do ovário ou maior. Fruto elipsóide, 12-15×8-10 mm, com cúpula recobrindo $1 / 2$ do fruto.

Material examinado: BRASIL. Paraná: Guaraqueçaba, 10/IV/1968, G. Hatschbach \& C. Koczicki 19008 (MBM, RB); Morretes, 10/X/1997, A.C. Nogueira 25 (EFC); São José dos Pinhais, 26/VII/1997, O.S. Ribas \& J.M. Silva 1938 (MBM); São José dos Pinhais, 17/V/2003, A. Dunainski Jr. \& W. Amaral 2061 (MBM).

Distribuição e ecologia: ocorre no México, América Central, porção Noroeste da América do Sul, chegando até a Bolívia. No Brasil, ocorre nos Estados do AM, BA, CE, MG, ES, RJ, SP e PR. Neste último Estado, a espécie foi registrada em FOD e FOM. Coletada com flores de abril a julho e com frutos em outubro.

Esta é a única espécie a apresentar a base foliar auriculada, com lobos voltados para a face abaxial, o que permite uma identificação segura.

\section{Agradecimentos}

Aos Dr. Renato Goldenberg e Pedro Luís Rodrigues de Moraes, pela orientação e co-orientação à primeira autora; ao Programa de Pós-Graduação da UFPR, pela oportunidade; à Diana Carneiro, pelas ilustrações e à CAPES pela concessão da bolsa.

\section{Referências bibliográficas}

APG II. 2003. An update of the Angiosperm Phylogeny Group classification for the orders and families of flowering plants: APG II. Botanical Journal of the Linnean Society 141: 399-436.

Bernardi, L. 1962. Lauráceas. Talleres Graficos Universitários. Mérida.

Baitello, J.B.; Lorea-Hernández, F.G.; Moraes, P.L.R.; Esteves, R. \& Marcovino, J.R. 2003. Lauraceae. Pp. 149-223. In: M.G.L. Wanderley; G.J. Shepherd; A.M. Giulietti \& T.S. Melhem (eds.). Flora Fanerogâmica do Estado de São Paulo. v.3. São Paulo, Fapesp-Rilla.

Chanderbali, A.S.; van der Werff, H. \& Renner, S.S. 2001. Phylogeny and historical biogeografy of Lauraceae: evidence from the chloroplast and nuclear genomes. Annals of the Missouri Botanical Garden 88: 104-134.

Cronquist, A. 1988. The Evolution an Classification of Flowering Plants. $2^{\text {nd }}$ ed. New York, The New York Botanical Garden.

Holmgren, P. K. \& Holmgren, N. H. 1998 (continuously updated). Index Herbariorum: A global directory of public herbaria and associated staff. New York Botancial Garden 's Virtual Herbarium. http://sweetgum.nybg.org/ih/ (Acessado em: 5/01/2007).

Judd, W.S.; Campbell, C.S.; Kellogg, E.A. \& Stevens, P.F. 1999. Plant systematic - a phylogenetic approach. Massachussetts, Sinauer.

IPNI 2008. The International Plant Names Index. http:// www.ipni.org/ipni/plantnamesearchpage.do (Acessado em: 18/03/2008).

Lawrence, G.H.M. 1951. Taxonomy of Vascular Plants. USA, The Macmillan Company.

Moraes, P.L.R. 2005. Sinopse das Lauráceas nos Estados de Goiás e Tocantins, Brasil. Biota Neotropica 5: 253-270.

Moraes, P.L.R. \& Oliveira, J.M.B. 2007. Lauraceae Juss. Pp. 1-154. In: J.A. Rizzo (coord.). Flora dos Estados de Goiás e Tocantins, Coleção Rizzo. v. 33. Goiânia, PRPPG/UFG.

Ribeiro, J.E.L.S.; Hopkins, M.J.G.; Vicentini, A.; Sothers, C.A.; Costa, M.A.S.; Brito, J.M.; Souza, M.A.D.; Martins, L.H.P.; Lohmann, L.G.; Assunção, P.A.C.L.; Pereira, E.C.; Silva, C.F.; Mesquita, M.R. \& Procópio, S.C. 1999. Flora da Reserva Ducke: guia de identificação das plantas vasculares de uma floresta de terra-firme na Amazônia Central. Manaus, Inpa.

Roderjan, C.V.; Galvão, F.; Kuniyoshi, Y.S. \& Hatschbach, G.G. 2002. As unidades fitogeográficas do Estado do Paraná. Ciência \& Ambiente 24: 75-92.

Rohwer, J.G. 1992. Notes on "Flora Ilustrada Catarinense, Lauráceas 6. Nectandra". Sellowia 42-44: 35-41.

Rohwer, J.G. 1993a. Lauraceae: Nectandra. Flora Neotropica, Monograph 60: 1-332.

Rohwer, J.G. 1993b. Lauraceae. Pp. 366-391. In: K. Kubitzki; J.G. Rohwer \& V. Bittrich (eds.). The families and genera of vascular plants. v.2. Berlim, Springer-Verlag.

Rohwer, J.G. 2000. Toward a phylogenetic classification of the Lauraceae: evidence from matK sequences. Systematic Botany 25: $60-71$.

Rohwer, J.G. \& Kubitzki, K. 1993. Ecogeographical differentiation in Nectandra (Lauraceae), and its historical implications. Botanica Acta 106: 88-99.

Werff, H. \& Richter, H.G. 1996. Toward an improved classsification of Lauraceae. Annals of the Missouri Botanical Garden 83: 409-418.

Versão eletrônica do artigo em www.scielo.br/abb e http://www.botanica.org.br/acta/ojs 